CLINICAL STUDY

\title{
Insulin levels measured with an insulin-specific assay in patients with fasting hypoglycaemia related to endogenous hyperinsulinism
}

\author{
Delphine Vezzosi, Antoine Bennet, Josette Fauvel ${ }^{1}$, Catherine Boulanger, Othman Tazi, Jean-Pierre Louvet \\ and Philippe Caron \\ Department of Endocrinology, Hôpital Rangueil, CHU Toulouse, 1 Avenue Jean-Poulhès, TSA 50032, 31059 Toulouse-Cedex 9, France and \\ ${ }^{1}$ Laboratory of Biochemistry III (Prof. H. Chap), Hôpital La Grave, CHU Toulouse, 31059 Toulouse-Cedex 9, France \\ (Correspondence should be addressed to P Caron; Email: caron.p@chu-toulouse.fr)
}

\begin{abstract}
Objective: The finding of insulin levels above a minimum threshold at the time of symptomatic hypoglycaemia is crucial in the diagnosis of endogenous hyperinsulinism. The aim of this study was to evaluate insulin levels at the time of hypoglycaemia with an insulin-specific assay in such patients. Design and methods: We measured insulin levels in 15 patients with fasting hypoglycaemia related to endogenous hyperinsulinism using an insulin-specific immunoradiometric assay (IRMA) without any significant cross-reaction with intact proinsulin.

Results: Insulin levels were below $6 \mathrm{mIU} / \mathrm{l}$ in all the samples taken at the time of symptomatic hypoglycaemia in 6/15 patients, and in some of the samples in three patients; insulin levels were below $3 \mathrm{mIU} / \mathrm{l}$ in samples from 5 patients. C-peptide levels were above $0.6 \mathrm{ng} / \mathrm{ml}$ in all these samples. The lowest proinsulin level was $35 \mathrm{pmol} / \mathrm{l}$. Insulin levels were measured with a less specific RIA (40\% cross-reaction with proinsulin) in $8 / 15$ patients and were above $6 \mathrm{mIU} / \mathrm{l}$ in all samples in seven patients, and all but one sample in the 8 th patient. Mean concomitant C-peptide and insulinoma size were lower in those patients with insulin-IRMA levels below $6 \mathrm{mIU} / \mathrm{l}$.

Conclusion: Symptomatic hypoglycaemia below $0.45 \mathrm{~g} / \mathrm{l}$ can result from insulin levels below 6 or even $3 \mathrm{mIU} / \mathrm{l}$; lower insulin levels and secretion could be observed preferentially in small insulinomas. If an insulin assay devoid of any significant cross-reaction with intact proinsulin is employed, measuring C-peptide (and/or proinsulin) levels at the time of symptomatic hypoglycaemia is mandatory to make the diagnosis of endogenous hyperinsulinism.
\end{abstract}

European Journal of Endocrinology 149 413-419

\section{Introduction}

Fasting hypoglycaemia related to endogenous hyperinsulinism can be assessed by measuring insulin levels during symptomatic fasting hypoglycaemia. The finding of a minimum serum insulin threshold at the time of symptomatic and biologically proven hypoglycaemia is admitted to be diagnostic of endogenous hyperinsulinism and is a crucial step in the diagnosis of insulinoma (1). Insulin levels can be measured either with assays using polyclonal antibodies leading to cross-reaction with proinsulin or with more recent assays employing specific monoclonal antibodies. The use of the latter assays is expanding, whereas older less specific assays are becoming unavailable. The recent assays are more sensitive as well as more specific than previous methods. Indeed, it is known that high proinsulin levels are observed in patients with insulinomas $(2,3)$. A minimum serum insulin threshold of $6 \mathrm{mIU} / \mathrm{l}$ (with concomitant symptomatic hypoglycaemia below $0.45 \mathrm{~g} / \mathrm{l})$ had been recommended using a double antibody radioimmunoassay with a detection limit of $5 \mathrm{mIU} / \mathrm{l}$ (1); others recommended a $5 \mathrm{mIU} / \mathrm{l}$ threshold with concomitant blood glucose below $0.54 \mathrm{~g} / \mathrm{l}$ (4). A lower threshold of $3 \mathrm{mIU} / \mathrm{l}$ was recommended with a recent immunochemiluminometric assay with a low detection limit (5). Some recent insulin assays are totally devoid of any significant crossreaction with intact proinsulin. We used such an immunoassay to evaluate insulin levels in patients with fasting hypoglycaemia related to endogenous hyperinsulinism in order to determine: (i) if the usually recommended insulin thresholds can be used for diagnosis of endogenous hyperinsulinism with such an insulin assay; (ii) if insulin levels measured with such an insulin-specific assay are related to specific characteristics among patients with endogenous hyperinsulinism. 


\section{Subjects and methods}

The 15 patients (10 female, five male) were aged 54.2 \pm 16.5 years (mean \pm s.D.) (range: $29-79$ years). Body mass index (BMI) was $24.7 \pm 4.00 \mathrm{~kg} / \mathrm{m}^{2}$ $\left(19.0-32.3 \mathrm{~kg} / \mathrm{m}^{2}\right.$ ) (see Table 1). In 10 patients (patients 1 to 10), an insulinoma was surgically removed after the investigations and the diagnosis of insulinoma was confirmed by histopathological examination. All insulinomas were considered to be benign based on microscopic criteria. In the remaining five patients (patients 11 to 15 ), measurement of blood glucose and $\mathrm{C}$-peptide during a fast test confirmed the diagnosis of fasting hypoglycaemia related to endogenous hyperinsulinism. These five patients had symptomatic hypoglycaemia with blood glucose below $0.45 \mathrm{~g} / \mathrm{l}$ and a concomitant inappropriate C-peptide level above $0.6 \mathrm{ng} / \mathrm{ml}$, which is diagnostic of endogenous hyperinsulinism according to Service and colleagues $(1,5,6)$; in addition, these patients also fulfilled the diagnosis criteria recommended by Marks and Teale (with a C-peptide level of at least $0.9 \mathrm{ng} / \mathrm{ml}$ with blood glucose below $0.54 \mathrm{~g} / \mathrm{l})(4)$. These five patients were successfully treated with diazoxide $(n=4$; patients $11,12,14,15)$ or octreotide $(n=1$; patient 13$)$ and not by surgery, because of (i) the age of the patient (patient 15), (ii) the diagnosis of hyperammoniaemic hyperinsulinism with no detectable tumour (patient 12), and (iii) the refusal of surgery by the patient (patients 11,13,14). Regarding liver and renal function, liver enzymes (ASAT, ALAT, gamma-GT) and creatinine clearance (calculated according to Cockroft's formula) were normal in all the patients except for minor abnormalities found in three patients, i.e. a minor increase in ALAT level in patient 7 (66 U/l, normal range $<55)$, a minor increase in gamma GT level in

Table 1 Clinical and biological features and histopathological findings in the 15 patients (patients $1-10$, histologically proven insulinomas; patients $11-15$, positive fast test).

\begin{tabular}{|c|c|c|c|c|c|}
\hline Patient & Sex & Age & BMI & $\begin{array}{c}\text { Creatinine } \\
\text { clearance }(\mathrm{ml} / \mathrm{min})\end{array}$ & $\begin{array}{c}\text { Insulinoma } \\
\text { size }(\mathrm{mm})\end{array}$ \\
\hline 1 & $\mathrm{~F}$ & 71 & 26.7 & 80 & 15 \\
\hline 2 & $\mathrm{~F}$ & 39 & 19.0 & 82 & 8 \\
\hline 3 & $\mathrm{~F}$ & 52 & 19.5 & 74 & 10 \\
\hline 4 & M & 56 & 28.6 & 82 & 10 \\
\hline 5 & $\mathrm{~F}$ & 78 & 25.6 & 61 & 12 \\
\hline 6 & $\mathrm{~F}$ & 68 & 32.3 & 99 & 19 \\
\hline 7 & $\mathrm{~F}$ & 71 & 28.1 & 53 & 22 \\
\hline 8 & $\mathrm{~F}$ & 55 & 20.9 & 87 & 19 \\
\hline 9 & M & 29 & 21.2 & 146 & 27 \\
\hline 10 & $\mathrm{~F}$ & 58 & 25.5 & 72 & 15 \\
\hline 11 & $M$ & 44 & 26.8 & 89 & \\
\hline 12 & $M$ & 30 & 23.9 & 137 & \\
\hline 13 & $M$ & 42 & 24.6 & 105 & \\
\hline 14 & $\mathrm{~F}$ & 41 & 19.6 & 69 & \\
\hline 15 & $\mathrm{~F}$ & 79 & 28.9 & 48 & \\
\hline
\end{tabular}

BMI, body mass index $\left(\mathrm{kg} / \mathrm{m}^{2}\right)$; creatinine clearance (in $\mathrm{ml} / \mathrm{min}$ ) calculated using Cockcroft's formula; insulinoma size (in $\mathrm{mm}$ ) is the greatest diameter - not determined in patients 11-15 who were not operated. patient 5 (87 U/l, normal range $<80)$, and low creatinine clearance in two patients $(53 \mathrm{ml} / \mathrm{min}$ in patient 7 , $48 \mathrm{ml} / \mathrm{min}$ in patient 15 ).

Blood glucose, serum insulin and C-peptide levels were measured during spontaneous symptomatic hypoglycaemia in 6 patients (patients 1, 2, 6, 7, 10, 11) and during a fast test in 13 patients (patients 2, 3, 4, 5, 6, 7, $8,9,11,12,13,14,15)$. The fast test was discontinued at the time when symptomatic hypoglycaemia occurred, with blood glucose below $0.45 \mathrm{~g} / \mathrm{l}$. In all but one patient ( = patient 4 ), at least two samples were taken with an interval of at least $1 \mathrm{~h}$ between the samples, before stopping the fast test; minor symptoms (anxiety, minor and transient dizziness) were not found to be sufficient to stop the test in eight patients, in whom more than two samples were taken at the time of hypoglycaemia below $0.45 \mathrm{~g} / \mathrm{l}$ associated with minor and finally more severe neuroglycopaenic symptoms (severe weakness, behavioural changes, obnubilation, confusion). The fast test lasted $20 \pm 20 \mathrm{~h}(2-70 \mathrm{~h})$; all patients reached blood glucose levels below $0.45 \mathrm{~g} / \mathrm{l}$ before the 48th hour of the fast, but the fast test was prolonged in two patients (patient 3: $50 \mathrm{~h}$, and patient 15: $70 \mathrm{~h}$ ) because the patients' symptoms before the 48th hour of fast were not judged to be specific by the supervising physician.

Among the available criteria for diagnosis of endogenous hyperinsulinism, we selected the lowest recommended blood glucose levels $(0.45 \mathrm{~g} / \mathrm{l}$ with symptoms of hypoglycaemia or $0.30 \mathrm{~g} / \mathrm{l}$ in an asymptomatic patient) (1). This choice was made in order to evaluate insulin levels at the time when there was an unequivocal inappropriate insulin secretion. No haemolysis could be visually detected in any of the samples used for measuring blood glucose and those used for measuring insulin levels. Blood glucose was measured within $15 \mathrm{~min}$ after taking the sample, using the glucose oxidase method. Insulin and C-peptide were measured in samples taken in dry Vacutainer tubes, immediately centrifuged, the sera being kept frozen at $-20^{\circ} \mathrm{C}$ until assayed.

Serum insulin levels were measured in all the samples with the IRMA Pasteur Bi-Insulin Biorad kit, provided by Pasteur Diagnostics (Marnes La Coquette, France) (= insulin-IRMA). This is an immunoradiometric assay (sandwich assay) which employs two monoclonal anti-insulin antibodies. One antibody is adsorbed on the tube walls, the other antibody is 125-I labelled. The samples are incubated with an excess of both antibodies. The cross-reactions (with all concentrations expressed in molar units) with C-peptide, proinsulin and split-fragments have been fully evaluated. There is no significant cross-reaction with intact proinsulin $\left(<10^{-4}\right)$ $\left(<3.10^{-3}\right.$ with $\mathrm{C}$-peptide, $<4.10^{-4}$ with split $32-33$ proinsulin, $<4.10^{-4}$ with des 31,32 proinsulin). The inter- and intra-assay coefficients of variation $(\mathrm{CV})$ are $8.0 \%$ and $3.8 \%$ respectively, and the lowest detectable level is $0.2 \mathrm{mIU} / \mathrm{l}(1.4 \mathrm{pmol} / \mathrm{l})$. The normal range for 
fasting serum levels is from 2 to $17 \mathrm{mIU} / \mathrm{l}$ (14.3 to $122 \mathrm{pmol} / \mathrm{l})$.

In the 29 serum samples taken from eight patients (patients 2, 6, 7, 8, 9, 13, 14, 15), serum insulin levels were also measured with the ERIA-Diagnostics Pasteur kit, an RIA kit using polyclonal antibodies provided by Pasteur Diagnostics (= insulin-RIA). The inter- and intra-assay $\mathrm{CV}$ are $6.4 \%$ and $5.8 \%$ respectively, and the lowest detectable level is $2.2 \mathrm{mIU} / \mathrm{l}$ $(15.8 \mathrm{pmol} / \mathrm{l})$. The normal range for fasting serum levels is from 5 to $20 \mathrm{mIU} / \mathrm{l}$ ( 35.9 to $143.5 \mathrm{pmol} / \mathrm{l})$. A $40 \%$ cross-reaction with intact proinsulin is observed with this assay.

C-peptide levels were measured with a radioimmunoassay. The RIA C-peptide CTK kit was purchased from Sorin Biomedica (Saluggia, Italy). This assay employs a polyclonal antibody with a $10 \%$ cross-reaction with intact proinsulin. It does not yield any significant cross-reaction with insulin, the antibodies not being directed against any part of the insulin molecule. The inter- and intra-assay CV are $12.64 \%$ and $4.45 \%$ respectively, and the lowest detectable level is $0.08 \mathrm{ng} / \mathrm{ml}$ $(0.025 \mathrm{nmol} / \mathrm{l})$. The normal range for fasting serum levels is from 0.5 to $3.0 \mathrm{ng} / \mathrm{ml}(0.17-1.00 \mathrm{nmol} / \mathrm{l})$.

Proinsulin was measured after an overnight fast and throughout the fast test in $8 / 15$ patients (patients 2,6 , $7,8,9,13,14,15)$ using the Human Proinsulin RIA kit, provided by Linco Research (St Charles, MO, USA). This assay employs a monoclonal antibody which reacts specifically with proinsulin. It yields no significant cross-reactivity with insulin $(<0.1 \%)$ or C-peptide $(0.1 \%)$. The inter- and intra-assay CV are $7.7 \%$ and $6.9 \%$ respectively. The lowest detectable level is $2 \mathrm{pmol} / \mathrm{l}$. The normal serum levels after an overnight fast are $7.9 \pm 1.5 \mathrm{pmol} / \mathrm{l}$.
Statistical analysis used a Mann-Whitney U test for comparisons between groups (Statview 5 program, SAS Institute Inc., Cary, NC, USA).

The present study was undertaken in agreement with the Helsinki Declaration of 1975, as revised in 1983.

\section{Results}

The results of blood glucose, insulin-IRMA, insulinRIA and C-peptide levels when blood glucose was below $0.45 \mathrm{~g} / \mathrm{l}$ are given in Table 2 . Blood glucose was found to be $0.45 \mathrm{~g} / \mathrm{l}$ or less either spontaneously or during the fast test in 52 samples collected in the 15 patients $(3.5 \pm 1.7$ samples per patient, mean \pm S.D.). Concomitant C-peptide levels were above the $0.6 \mathrm{ng} / \mathrm{ml}$ threshold defined by Service and colleagues $(1,5,6)$ in all these samples; the lowest $C$-peptide level $(0.7 \mathrm{ng} / \mathrm{ml})$ was observed in a patient with an histologically proven insulinoma. Concomitant insulin-RIA levels were evaluated in the 29 serum samples taken from eight of the 15 patients and were above the $6 \mathrm{mIU} / \mathrm{l}$ threshold in all but one sample (one of the two samples taken from patient 14). Regarding the results observed with the IRMA insulin-specific assay, in the 52 samples taken from the 15 patients at the time of symptomatic hypoglycaemia of $0.45 \mathrm{~g} / \mathrm{l}$ or less, insulin-IRMA levels were below $6 \mathrm{mIU} / \mathrm{l}$ in all the serum samples in six patients (patients 2, 3, 4, $5,13,14)$, and in some of the serum samples in three patients $(1,9,15)$; insulin-IRMA levels even reached values below $3 \mathrm{mIU} / \mathrm{l}$ in five patients $(2,3$, $4,13,14)$. Insulin-IRMA exceeded the $6 \mathrm{mIU} / \mathrm{l}$ threshold in all the serum samples in only six patients $(6,7,8,10,11,12)$.

Table 2 Results of blood glucose, insulin-IRMA, insulin-RIA and C-peptide levels observed before surgery at the time of symptomatic hypoglycaemia of $0.45 \mathrm{~g} / \mathrm{l}$ or less in the 15 patients. $\mathrm{N}=$ number of samples taken at the time of hypoglycaemia below $0.45 \mathrm{~g} / \mathrm{l} ; \mathrm{N}<6$ : number of samples with insulin-IRMA levels below $6 \mathrm{mIU} / \mathrm{l} ; \mathrm{N}<3$ : number of samples with insulin-IRMA levels below $3 \mathrm{mIU} / \mathrm{l}$. Results of insulin-IRMA ( = IRMA) (mIU/l), insulin-RIA (= RIA) (mIU/l), C-peptide (ng/ml) and blood glucose (= B. glucose) (g/l) are given as ranges of values.

\begin{tabular}{lccccccc}
\hline Patient & $\mathbf{N}$ & $\mathbf{N}<\mathbf{6}$ & $\mathbf{N}<\mathbf{3}$ & IRMA & RIA & C-peptide & B. glucose \\
\hline 1 & 4 & 2 & 0 & $3.0-8.0$ & ND & $1.4-4.6$ & $0.31-0.38$ \\
2 & 5 & 5 & 8 & $1.0-3.0$ & $26.0-26.0$ & $2.1-2.5$ & $0.35-0.39$ \\
3 & 8 & 8 & $1.0-5.0$ & ND & $0.7-2.6$ & $0.27-0.42$ \\
4 & 1 & 1 & 1 & ND & 0.44 \\
5 & 2 & 2 & 0 & $3.4-5.0$ & ND & $3.2-3.2$ & $0.20-0.45$ \\
6 & 5 & 0 & 0 & $14.0-29.0$ & $20.0-32.0$ & $4.9-6.3$ & $0.31-0.42$ \\
7 & 3 & 0 & 0 & $25.0-45.0$ & $57.0-80.0$ & $6.4-7.7$ & $0.23-0.39$ \\
8 & 3 & 0 & 0 & $18.0-37.0$ & $61.0-86.0$ & $4.4-7.6$ & $0.22-0.32$ \\
9 & 4 & 1 & 0 & $5.7-8.0$ & $55.0-61.0$ & $2.6-3.1$ & $0.36-0.42$ \\
10 & 3 & 0 & 0 & $6.0-18.0$ & ND & $4.7-5.4$ & $0.32-0.43$ \\
11 & 3 & 0 & 0 & $7.0-20.0$ & ND & $2.4-4.1$ & $0.33-0.45$ \\
12 & 2 & 0 & 0 & $8.0-11.0$ & ND & $0.9-1.0$ & $0.44-0.44$ \\
13 & 2 & 2 & 1 & $2.9-3.3$ & $42.0-42.0$ & $3.2-3.2$ & $0.38-0.43$ \\
14 & 2 & 2 & 2 & $1.0-1.0$ & $5.0-10.0$ & $1.1-1.1$ & $0.35-0.43$ \\
15 & 5 & 3 & 0 & $3.1-8.1$ & $11.0-27.0$ & $3.2-4.3$ & $0.39-0.45$ \\
\hline
\end{tabular}

ND, not determined. 
Proinsulin levels were high either after an overnight fast $(121 \pm 117 \mathrm{pmol} / \mathrm{l}$, range: $35-365)$ or at the time of fast-induced hypoglycaemia $(168 \pm 155 \mathrm{pmol} / \mathrm{l}$, range: 35-425); when proinsulin was measured after an overnight fast, concomitant blood glucose was below $0.45 \mathrm{~g} / \mathrm{l}$ in four patients $(2,7,8,9)$ and above $0.45 \mathrm{~g} / \mathrm{l}$ in the other four patients $(6,13,14,15)$.

Those of the patients with endogenous hyperinsulinism in whom symptomatic hypoglycaemia was caused by insulin-IRMA levels below $6 \mathrm{mIU} / \mathrm{l}$ (group $1, n=6$, patients $2,3,4,5,13,14$ ) were compared with those of the patients in whom the occurrence of symptomatic hypoglycaemia was always associated with insulinIRMA levels above $6 \mathrm{mIU} / \mathrm{l}$ (group 2, $n=6$, patients 6 , $7,8,10,11,12)$, to ascertain if low insulin levels in such patients are associated with specific features; the three patients (1,9 and 15) in whom symptomatic hypoglycaemia was associated with insulin-IRMA levels either below or above $6 \mathrm{mIU} / \mathrm{l}$ were excluded from the groups, in order to create a clear cut-off between the groups compared (see Table 3). Group 1 patients, with the lower insulin-IRMA levels, were found also to have lower concomitant C-peptide levels $(P<0.01)$. No difference was found regarding concomitant mean blood glucose levels. Table 3 also shows that group 1 patients did not differ significantly from group 2 patients regarding their age, and that they tended to have lower mean BMI, although the difference did not reach significance. No significant difference was found regarding liver enzyme levels or creatinine estimated clearance (Cockroft's formula). Regarding the patients who underwent surgical removal of the insulinoma (four patients in each

Table 3 Comparison between the six patients with all insulinIRMA levels below $6 \mathrm{mIU} / \mathrm{l}$ (at the time of symptomatic hypoglycaemia of $0.45 \mathrm{~g} / \mathrm{l}$ or less) (= group 1 , no. of patients, 6 ; no. of serum samples, 20) and the 6 patients with all insulin-IRMA levels above $6 \mathrm{mlU} / \mathrm{l}$ ( = group 2, no. of patients, 6; no. of serum samples, 19). Results of blood glucose, C-peptide and insulin are calculated from all samples taken at the time of symptomatic hypoglycaemia below $0.45 \mathrm{~g} / \mathrm{l}$. Creatinine clearance is calculated based on Cockroft's formula. Insulinoma size was calculated based on the results of eight operated patients (four in each group). All results are expressed as means \pm S.D. Comparisons are made using Mann-Whitney $U$ test.

\begin{tabular}{lllc}
\hline & Group I & Group 2 & \multicolumn{1}{c}{$\boldsymbol{P}$} \\
\hline Age (years) & $51.3 \pm 14.7$ & $54.3 \pm 15.3$ & N.S. \\
BMl $\left(\mathrm{kg} / \mathrm{m}^{2}\right)$ & $22.8 \pm 4.0$ & $26.2 \pm 3.9$ & N.S. \\
ASAT $(\mathrm{U} / \mathrm{l})$ & $17.1 \pm 5.0$ & $24.7 \pm 7.2$ & N.S. \\
ALAT $(\mathrm{U} / \mathrm{l})$ & $26.8 \pm 6.3$ & $36.2 \pm 18.7$ & N.S. \\
Gamma-GT $(\mathrm{U} / \mathrm{l})$ & $42.3 \pm 27.8$ & $32.5 \pm 15.8$ & N.S. \\
Creatinine clearance $(\mathrm{ml} / \mathrm{min})$ & $78.9 \pm 15.2$ & $89.5 \pm 28.3$ & N.S. \\
Insulinoma size $(\mathrm{mm})$ & $10.0 \pm 1.6$ & $18.7 \pm 2.9$ & $<0.05$ \\
Blood glucose $(\mathrm{g} / \mathrm{l})$ & $0.38 \pm 0.06$ & $0.36 \pm 0.07$ & N.S. \\
C-peptide $(\mathrm{ng} / \mathrm{ml})$ & $2.15 \pm 0.76$ & $4.89 \pm 2.04$ & $<0.01$ \\
\hline
\end{tabular}

N.S., not significant.

The normal ranges for liver enzymes are as follows: ASAT: $<40 \mathrm{U} /$; ALAT: $<55 \mathrm{U} /$ /; gamma-GT: $<80 \mathrm{U} / \mathrm{l}$. group), the size of the insulinoma was lower $(P<0.05)$ in group 1 patients.

\section{Discussion}

The first step in the diagnosis of fasting hypoglycaemia related to endogenous hyperinsulinism is to find biological hypoglycaemia $(<0.45 \mathrm{~g} / \mathrm{l}$ according to Service) (1) during autonomic or neuroglycopaenic clinical symptoms, occurring either spontaneously or during a 72-h fast test, which is known to be the gold standard for the diagnosis of organic hypoglycaemic disorders (1). Since mild autonomic symptoms may often be lacking in patients suffering from such disorders, the decision to discontinue the fast test can be made in an asymptomatic patient when blood glucose falls below $0.30 \mathrm{~g} / \mathrm{l}(1.65 \mathrm{mmol} / \mathrm{l})(1)$. Then the second and crucial step for the diagnosis of insulinoma is to show inappropriate insulin levels at the time of hypoglycaemia. To date, based on previous studies with a double antibody insulin radioimmunoassay (with a detection limit of $5 \mathrm{mIU} / \mathrm{l}$ ), the minimum threshold of $6 \mathrm{mIU} / \mathrm{l}(43 \mathrm{pmol} / \mathrm{l})$ at the time of hypoglycaemia has been recommended as the diagnostic criterion of inappropriate insulin secretion responsible for fasting hypoglycaemia; an almost similar serum insulin threshold of $5 \mathrm{mIU} / \mathrm{l}$ (with concomitant blood glucose levels below $0.54 \mathrm{~g} / \mathrm{l}$ ) has been recommended by others (4). More recently, a $3 \mathrm{mIU} / \mathrm{l}$ insulin threshold was suggested to be diagnostic of inappropriate insulin secretion when insulin is measured with an immunochemiluminometric assay, with a detection limit below $1 \mathrm{mIU} / \mathrm{l}$ (5).

In our study, using an immunoradiometric insulinspecific assay devoid of any significant cross-reaction with intact proinsulin, we found insulin levels below $6 \mathrm{mIU} / \mathrm{l}$ at the time of hypoglycaemia below $0.45 \mathrm{~g} / \mathrm{l}$ in at least one sample taken from $9 / 15$ patients and in all the samples taken at the time of hypoglycaemia in 6/15 patients. Thus diagnosis of endogenous hyperinsulinism and insulinoma would not have been made in at least $6 / 15$ patients if the minimum threshold of $6 \mathrm{mIU} / \mathrm{l}$ for serum insulin had been used as the only diagnostic criterion. Even values below $3 \mathrm{mIU} / \mathrm{l}$ were observed in 5 of our patients at the time of symptomatic hypoglycaemia below $0.45 \mathrm{~g} / \mathrm{l}$. On the other hand, C-peptide levels were above $0.6 \mathrm{ng} / \mathrm{ml}$ in all these samples, which provided evidence for endogenous hyperinsulinism, as already reported by Service and colleagues $(1,5,6)$; only one patient with an histologically proven insulinoma did not reach the $0.9 \mathrm{ng} / \mathrm{ml}$ serum C-peptide threshold recommended by Marks and Teale (4). Insulin levels were measured with a less specific insulin-RIA in 8/15 patients comprising 5 of the 9 patients in whom insulin-IRMA levels were below $6 \mathrm{mIU} / \mathrm{l}$ and were found to be above $6 \mathrm{mIU} / \mathrm{l}$ in all but one sample. 
It is known that the occurrence of haemolysis in the sample used for evaluation of insulin levels results in artefactual changes in insulin levels (7). Red cells contain an insulin-degrading enzyme which may lead to underestimation of the actual insulin concentrations in haemolysed samples. There was no visual evidence of haemolysis in any of the samples used for measurement of insulin levels in our study.

Other studies had previously reported a few cases of insulinomas with insulin levels below $6 \mathrm{mIU} / \mathrm{l}$ at the time of fasting hypoglycaemia below $0.45 \mathrm{~g} / \mathrm{l}(2,8)$, even with less specific insulin assays. Due to structural homology between insulin and proinsulin, measuring the actual insulin concentration in serum requires highly specific antibodies. Evaluation of insulin levels with methods with poor specificity using polyclonal antibodies yields $40-80 \%$ cross-reactivity with proinsulin. On a theoretical basis, it has already been suggested that using more specific insulin assays could lead to increasing difficulties for showing inappropriate insulin levels in patients with endogenous hyperinsulinism $(4,9)$. In healthy subjects, insulin molecular concentration in plasma is only fivefold that of proinsulin. It is known that a high proportion of proinsulin is secreted by insulinomas (10). Molecular concentrations of insulin and proinsulin in plasma are very similar in patients with insulinoma, so that the percentage of cross-reaction with proinsulin strongly affects the results of plasma insulin. New immunoradiometric or immunoenzymologic assays have been recently designed, using specific monoclonal antibodies, and leading to lower minimum detectable concentrations of insulin. If an immmunochemiluminometric assay with a low detection limit (below $1 \mathrm{mIU} / \mathrm{l}$ ) is employed, a $3 \mathrm{mIU} / \mathrm{l}$ threshold is recommended (5). Using such an immunochemiluminometric assay (ADVIA Centaur) in 325 serum samples collected in control subjects $(n=71$ samples $)$ and patients ( $n=254$ serum samples taken from in-patients staying in our department or the Department of Diabetology of our hospital) with diabetes mellitus, glucose intolerance or insulinoma, we found insulin levels slightly above the results obtained with the IRMA in all categories of subjects, with a good correlation between the results of the two insulin assays: all subjects: $n=325$, $\mathrm{R}=0.97, P<0.01$, equation of the regression line: Insulin ADVIA Centaur $=1.235 \quad($ IRMA $)+5.4667$; controls: $n=71, \mathrm{R}=0.97, P<0.01$, equation of the regression line: Insulin ADVIA Centaur $=1.2677$ (IRMA)+1.2401; insulinoma patients: $n=18$, $\mathrm{R}=0.97, P<0.01$, equation of the regression line: Insulin ADVIA Centaur $=1.279 \quad($ IRMA) +1.4387 (11). However, to date, there is no available full characterisation of the cross-reactions observed with proinsulin and split fragments with the ADVIA Centaur insulin assay. With the IRMA employed in our study, i.e. an assay totally devoid of any cross-reaction with intact proinsulin, even insulin levels below $3 \mathrm{mIU} / \mathrm{l}$ were observed at the time of symptomatic hypoglycaemia below $0.45 \mathrm{~g} / \mathrm{l}$. According to a recent case report (12), insulin levels of $1.6 \mathrm{mIU} / \mathrm{l}$ and less than the detection limit of the assay $(<2 \mathrm{mIU} / \mathrm{l})$ were found at the time of hypoglycaemia with two specific insulin assays in a patient with an insulinoma. Serum insulin half-life is very short (about $4 \mathrm{~min}$ ) in subjects with normal metabolic clearance of insulin, so one might suspect that even detectable insulin levels at the time of symptomatic fasting hypoglycaemia (usually after several hours of fast) might be inappropriate. On a practical basis, since several new sensitive insulin assays are to become widely used in the laboratories (the older less specific insulin RIAs becoming unavailable), we conclude that clinical practitioners should be aware that there is no universal minimum insulin threshold for all new insulin-sensitive assays and that the published insulin thresholds for the diagnosis of inappropriate insulin secretion cannot be used without evaluating the assay employed. Based on our data with three different insulin assays (the IRMA, the RIA and the ADVIA Centaur immunochemiluminometric assay), and on our finding that insulin levels, when measured with an insulin-specific IRMA, are lower in many patients than the diagnostic thresholds reported by others with other assays, it can be concluded that the results of insulin levels appear to be highly dependent on the assay employed and on its cross-reactivity with intact proinsulin.

On the other hand, the C-peptide assay now in use in our laboratory displays a 10\% cross-reactivity with proinsulin. Previously used C-peptide RIAs yielded higher percentages of cross-reaction with proinsulin (65\% and 45\% respectively for RIA Byk Sangtec Diagnostica kit and the ERIA Diagnostics Pasteur kit previously used in our laboratory). The specificity of C-peptide assays has improved. However, plasma proinsulin molecular concentration is 50 times smaller than that of C-peptide. The percentage of cross-reaction with proinsulin does not affect, to a large extent, the results of plasma C-peptide, so that the result of plasma C-peptide is not so closely dependent on the assay employed as that of plasma insulin. This is in keeping with the confirmation of the previously established (6) $0.6 \mathrm{ng} / \mathrm{ml}$ threshold by Service when a new immunochemiluminometric assay was employed to measure C-peptide levels (5). In all our patients, C-peptide levels exceed the minimum threshold of $0.6 \mathrm{ng} / \mathrm{ml}$, even when measured with an assay with good specificity. This minimum threshold for C-peptide levels, concomitant with blood glucose below $0.45 \mathrm{~g} / \mathrm{l}$, had already been reported to be a better criterion for diagnosis of insulinomas than the $6 \mathrm{mIU} / \mathrm{l}$ threshold for insulin levels (6).

The present study shows that if an insulin-specific assay is used to measure insulin, taking account of the C-peptide threshold is mandatory in order not to miss the diagnosis of endogenous hyperinsulinism. 
Since two different thresholds $(0.6 \mathrm{ng} / \mathrm{ml}$ and $0.9 \mathrm{ng} / \mathrm{ml}$ ) have been published for C-peptide levels at the time of hypoglycaemia $(4,5)$ it is likely that the C-peptide threshold also partly depends on the assay employed; based on our data and on the improving specificity of the C-peptide assays, the lower threshold (i.e. $0.6 \mathrm{ng} / \mathrm{ml}$ ), which has been confirmed as valid with an immunochemiluminometric assay (5), is to be chosen preferentially. However, one must bear in mind that there is no available insulin or C-peptide threshold in subjects with altered insulin and C-peptide clearance rate (13). In addition, it has been shown that there is an overlap between C-peptide levels found in controls and in patients with insulinoma, when the range of blood glucose level is $0.5-0.6 \mathrm{~g} / \mathrm{l}$ at the end of the fast; under such conditions, plasma betahydroxy-butyrate and blood glucose response to glucagon are better than C-peptide levels to distinguish patients from controls (14).

It is known that the proportion of proinsulin secreted by insulinomas is high $(2,3)$. Based on our data and on previous studies by others $(1,2,5)$, proinsulin appears to be an interesting parameter in the evaluation of patients with fasting hypoglycaemia. A $5 \mathrm{pmol} / \mathrm{l}$ proinsulin threshold at the end of the fast test (with concomitant hypoglycaemia below $0.45 \mathrm{~g} / \mathrm{l}$ ) has been recommended by Service $(1,5)$ for the diagnosis of endogenous hyperinsulinism. According to Hirshberg et al. (2), a $22 \mathrm{pmol} / \mathrm{l}$ proinsulin threshold was found to be the best cut-off value to distinguish insulinoma patients from control subjects, either at the beginning of the fast test (regardless of concomitant blood glucose levels) or at the end of a fast test. Plasma proinsulin was above $22 \mathrm{pmol} / \mathrm{l}$ after an overnight fast, and above $22 \mathrm{pmol} / \mathrm{l}$ (and, consequently, above $5 \mathrm{pmol} / \mathrm{l}$ ) at the time of fast-induced hypoglycaemia in our patients. However, plasma proinsulin was found to be $12 \mathrm{pmol} / \mathrm{l}$ and $11 \mathrm{pmol} / \mathrm{l}$ when measured twice after an overnight fast in another patient (not reported here) who was finally found to have endogenous hyperinsulinism related to multiple islet cell micronodules of the pancreas (concomitant blood glucose levels were normal, $0.8 \mathrm{~g} / \mathrm{l})$. In nine control subjects in whom normal blood glucose levels during the 72 -h fast test ruled out the diagnosis of insulinoma, we found that proinsulin levels were $7.5 \pm 3.4 \mathrm{pmol} / \mathrm{l}$ (range: $3.5-$ $15 \mathrm{pmol} / \mathrm{l})$ after an overnight fast and $5.2 \pm 3.0 \mathrm{pmol} / \mathrm{l}$ (range $2-12 \mathrm{pmol} / \mathrm{l}$ ) at the end of the $72-\mathrm{h}$ fast test. Even if proinsulin levels are above $22 \mathrm{pmol} / \mathrm{l}$ in a nonobese patient suspicious of having endogenous hyperinsulinism, concomitant hypoglycaemia is necessary to make the diagnosis, as pointed out by Service $(1,5)$ and also by Hirshberg et al. (2). The half-life of proinsulin is longer than that of C-peptide, and a longer duration of hypoglycaemia is necessary to reduce proinsulin levels in patients in whom fasting hypoglycaemia is not caused by endogenous hyperinsulinism; in addition, to date, there is no rapid automated method to measure proinsulin, whereas such methods can be used for evaluation of C-peptide, so that measuring blood glucose and C-peptide can lead very quickly to the diagnosis of fasting hypoglycaemia related to endogenous hyperinsulinism. Further study seems necessary to ascertain whether establishing a proinsulin threshold at the time of hypoglycaemia could be a better criterion than using the established C-peptide threshold. Those patients with lower insulin-IRMA levels were also found to have lower concomitant C-peptide and insulinRIA levels than the other patients, and similar liver enzyme levels and mean creatinine clearance, which suggests that their actual insulin secretion was lower than that of the other patients.

Mean insulinoma size was also found to be smaller in those patients with lower insulin-IRMA levels at the time of hypoglycaemia. Thus insulin secretion in insulinomas appears to be, at least partly, related to the size of the tumour, as already observed with other endocrine tumours (15); one practical consequence is that in patients with insulinomas and low insulinIRMA levels, visualisation of the insulinoma by radiological investigations is likely to be more difficult, which emphasizes the importance of knowing that low insulin-IRMA levels do not rule out the diagnosis when blood glucose and C-peptide levels provide diagnostic evidence for endogenous hyperinsulinism.

Finally, using a highly insulin-specific insulin assay devoid of any significant cross-reaction shows that insulin levels do not need to reach $6 \mathrm{mIU} / \mathrm{l}$ to elicit hypoglycaemia below $0.45 \mathrm{~g} / \mathrm{l}$ in several patients with endogenous hyperinsulinism. Since concomitant blood glucose levels were similar in all the patients, insulin sensitivity is likely to be higher in such patients with lower insulin-IRMA levels, which is in keeping with the finding that they tended to have lower mean BMI.

In summary, insulin levels measured at the time of fasting hypoglycaemia in patients with endogenous hyperinsulinism with an insulin assay (insulin-IRMA) totally devoid of any significant cross-reaction with intact proinsulin were found to be lower than the usual threshold of $6 \mathrm{mIU} / \mathrm{l}$ in all the samples taken from $6 / 15(40 \%)$ patients, and in some of the samples in 3/15 patients; insulin-IRMA levels could reach values below $3 \mathrm{mIU} / \mathrm{l}$, which has been suggested to be the threshold to be used in conjunction with the new immunochemiluminometric assays with a low detection limit. In all the patients, all concomitant C-peptide levels were above the $0.6 \mathrm{ng} / \mathrm{ml}$ threshold when measured with an RIA with little cross-reaction with intact proinsulin and no cross-reaction with insulin. Differences in insulin levels evaluated with an insulin-specific assay are associated with differences regarding concomitant C-peptide levels and appear to be related to insulinoma size. A higher insulin sensitivity and a lower secretion of insulin are likely in patients with low insulin-IRMA levels. On a practical 
basis, one must be aware that missing the diagnosis of insulinoma could be frequent if the threshold of $6 \mathrm{mIU} / \mathrm{l}$ at the time of hypoglycaemia is used with the highly insulin-specific insulin assays, devoid of any significant cross-reaction with proinsulin, which are now available and widely used in laboratories; the threshold is highly dependent on the method used to measure insulin and it is likely that there is no universal threshold for the diagnosis for all the highly sensitive methods now available to measure insulin. Since old insulin assays are becoming unavailable, such insulin-specific assays are now being used, and it is mandatory to consider C-peptide levels and/or presumably proinsulin levels, if available (2, $3,4,6)$, at the time of hypoglycaemia, before ruling out the diagnosis of insulinoma.

\section{References}

1 Service FJ. Hypoglycemic disorders. New England Journal of Medicine 199527 1144-1152.

2 Hirshberg B, Livi A, Bartlett DL, Libutti SK, Alexander HR, Doppman JL et al. Forty-eight-hour fast: the diagnostic test for insulinoma. Journal of Clinical Endocrinology and Metabolism $2000853222-3226$.

3 Kao PC, Taylor RL \& Service FJ. Proinsulin by immunochemiluminometric assay for the diagnosis of insulinoma. Journal of Clinical Endocrinology and Metabolism 199478 1048-1051.

4 Marks V \& Teale JD. Investigation of hypoglycaemia. Clinical Endocrinology 199644 133-136.

5 Service FJ. Diagnostic approach to adults with hypoglycaemic disorders. Endocrinology and Metabolism Clinics of North America 199928 519-532.
6 Service FJ, O'Brien PC, McMahon MM \& Kao PC. C-peptide during the prolonged fast in insulinoma. Journal of Endocrinology and Metabolism $1993 \mathbf{7 6}$ 655-659.

7 O'Rahilly S, Burnett MA, Smith RF, Darley JH \& Turner RC. Haemolysis affects insulin but not C-peptide immunoassay. Diabetologia $198730394-396$.

8 Fajans SS \& Vinik AI. Insulin-producing islet cell tumors. Endocrinology and Metabolism Clinics of North America 198918 $45-74$.

9 Gorden P, Skarulis MC, Roach P, Comi RJ, Fraker DL, Norton JA et al. Plasma proinsulin-like component in insulinomas: a 25-year experience. Journal of Endocrinology and Metabolism $1995802884-2887$.

10 Rastogi GK, Sinha MK \& Dash RJ. Insulin and proinsulin content of pancreases from diabetic and nondiabetic subjects. Diabetes 197322 804-807.

11 Fauvel J, Vezzosi D, Ayon F \& Chap H. Evaluation des dosages de l'insuline et du peptide-C sérique sur l'automate ADVIA Centaur. Communication. CORATA 19ème Colloque, Lyon, France, 22-24 October 2002.

12 Chia CW \& Saudek CD. The diagnosis of fasting hypoglycaemia due to an islet-cell tumor obscured by a highly specific insulin assay. Journal of Clinical Endocrinology and Metabolism $2003 \mathbf{8 8}$ 1464-1467.

13 Basu A, Sheehan MT, Thompson GB \& Service FJ. Insulinoma in chronic renal failure: a case report. Journal of Clinical Endocrinology and Metabolism $2002874889-4891$.

14 O'Brien T, O'Brien PC \& Service FJ. Insulin surrogates in insulinoma. Journal of Clinical Endocrinology and Metabolism $1993 \mathbf{7 7}$ $448-451$.

15 Lenders JWM, Pacak K \& Eisenhofer G. New advances in the biochemical diagnosis of pheochromocytoma. Annals of the New York Academy of Sciences 2002970 29-40.

Received 17 April 2003

Accepted 15 July 2003 